\title{
CP-31398 attenuates endometrial cancer cell invasion, metastasis and resistance to apoptosis by downregulating MDM2 expression
}

\author{
LING LIU $^{1 *}$, LI YANG ${ }^{1 *}$, HUI CHANG ${ }^{2}$, YAN-NAN CHEN ${ }^{1}$, FENG ZHANG $^{1}$, \\ SHUO FENG ${ }^{1}$, JUAN PENG ${ }^{1}$, CHEN-CHEN REN $^{3}$ and XIAO-AN ZHANG ${ }^{4}$
}

\author{
${ }^{1}$ Department of Gynecologic Oncology; ${ }^{2}$ Laboratory of Tumor Precision Medicine; Departments of ${ }^{3}$ Obstetrics and \\ Gynecology, and ${ }^{4}$ Imaging, The Third Affiliated Hospital of Zhengzhou University, Zhengzhou, Henan 450052, P.R. China
}

Received February 5, 2018; Accepted October 26, 2018

DOI: 10.3892/ijo.2019.4681

\begin{abstract}
Endometrial cancer (EC) is one of the most common malignancies of the female reproductive system, and metastasis is a major cause of mortality. In this study, we aimed to explore the role of CP-31398 in the migration, invasion and apoptosis of EC cells by its regulation of the expression of the murine double minute 2 (MDM2) gene. For this purpose, EC tissues and adjacent normal tissues were collected, and the positive expression rate of MDM2 in these tissues was assessed. Subsequently, the cellular 50\% inhibitory concentration (IC50) of CP-31398 was measured. The EC RL95-2 and KLE cell lines had a higher MDM2 expression and were thus selected for use in subsequent experiments. The EC cells were then treated with CP-31398 $(2 \mu \mathrm{g} / \mathrm{ml})$, and were transfected with siRNA against MDM2 or an MDM2 overexpression plasmid in order to examine the effects of CP-31398 and MDM2 on EC cell activities. The expression of p53, p21, Bad, Bax, B-cell lymphoma-2 (Bcl-2), cytochrome $c$ (Cyt-c), caspase-3, Cox-2, matrix metalloproteinase (MMP)-2 and MMP-9 was measured to further confirm the effects of CP-31398 on cell migration, invasion and apoptosis. Our results indicated that MDM2 was highly expressed in EC tissues. Notably, EC cell viability decreased with the increasing concentrations of CP-31398. The EC cells treated with CP-31398 or siRNA against MDM2 exhibited an increased apoptosis and a suppressed migration and invasion, corresponding to an increased expression of $\mathrm{p} 53$,
\end{abstract}

Correspondence to: Dr Xiao-An Zhang, Department of Imaging, The Third Affiliated Hospital of Zhengzhou University, 7 Front Kangfu Street, Zhengzhou, Henan 450052, P.R. China

E-mail: zxa@zzu.edu.cn

Dr Chen-Chen Ren, Department of Obstetrics and Gynecology, The Third Affiliated Hospital of Zhengzhou University, 7 Front Kangfu Street, Zhengzhou, Henan 450052, P.R. China

E-mail: renchenchen1106@163.com

"Co-first authorship

Key words: CP-31398, murine double minute 2, endometrial cancer, apoptosis, migration, invasion p21, Bad, Bax, Cyt-c and caspase-3, as well as to a decreased expression of Bcl-2, Cox-2, MMP-2 and MMP-9. Moreover, treatment with CP-31398 and siRNA against MDM2 further enhanced these effects. Taken together, the findings of this study indicate that the CP-31398-mediated downregulation of MDM2 may suppress EC progression via its inhibitory role in EC cell migration, invasion and resistance to apoptosis. Therefore, treatment with CP-31398 may prove to be possible therapeutic strategy for EC.

\section{Introduction}

Endometrial cancer (EC) is the most common gynecological malignancy, affecting over 280,000 women worldwide each year (1). In terms of incidence, the mortality of EC has increased substantially (by 21\%) since 2008, and the death rate has doubled over the past two decades (2). Endometrioid adenocarcinoma or endometrioid EC is the most common histological subtype and accounts for $75-80 \%$ of all EC cases (3). EC primarily affects post-menopausal women $(91 \%$ of cases in women aged $<50$ years) (4). Obesity is a key risk factor for EC, which is largely due to the high estrogen levels in obese women (5). Lymph-vascular space invasion presents a major adverse prognostic factor in patients with EC (6), and the lymph-vascular space invasion is one of the risk factors for recurrence. Diabetes and hypertension have also been reported to be closely associated with EC (7). A previous study found that the risk of EC in women with polycystic ovary syndrome (PCOS) was 3-fold was as high as that in those without PCOS (8). Surgical treatment is the first-line therapy; however, the effectiveness of surgical means is sub-satisfactory, and the scope of lymphadenectomy is limited (9). Thus, a better understanding of the molecular mechanisms underlying the aggressive behavior of EC is necessary to identify potential targets for effective therapy.

C P-31398 (N'-[2-[2-(4-methoxyphenyl) ethenyl]-4-quinazolinyl]-N,N-dimethyl-1,3-propanediamine dihydrochloride) is a styryl quinazoline that allows the DNA binding domain of p53 to maintain the activity of p53 as a transcription factor and tumor inhibitor (10). A previous study found that CP-31398 plays an important role in the prevention and treatment of skin, liver and colon cancers (11) and that CP-31398 can inhibit the development and invasion of urothelial 
bladder transitional cell carcinoma in vivo (12). In vitro and in vivo, CP-31398 has also been found to prevent the migration and invasion of hepatocellular carcinoma cells (13), colorectal cancer cells (14) and pancreatic cancer cells (15) induced by p53 deletion. In rhabdomyosarcoma, CP-31398 has been shown to increase the expression of p53 and its downstream transcriptional targets, p21 and murine double minute 2 (MDM2) (16). MDM2, which is located on chromosome 12q14.3-15 and contains 11 exons, is an oncoprotein and a key negative regulator of p53 (17). MDM2 has been implicated in the pathogenesis of various types of cancer, such as cancer of the breast, cervix and ovary (18-20). The overexpression of MDM2 has been found in intestinal metaplasia and gastric cancer, indicating that MDM2 overexpression may be a cause of tumor formation (21). As regards the association between CP-31398 and MDM2, a previous study found that CP-31398 can stabilize wild-type p53 in cells by suppressing the ubiquitination and degradation mediated by MDM2 (22). From all the above, we hypothesized that CP-31398 may play a role in the migration, invasion and apoptosis of EC cells through the MDM2 gene and in this study, we thus aimed to elucidate this role by means of experimentation on EC tissues.

\section{Materials and methods}

Ethics statement. This study was approved by the Clinical Ethics Committee of The Third Affiliated Hospital of Zhengzhou University, Zhengzhou, China. Informed consents were obtained from all subjects participating in this study.

Study subjects. A total of 83 EC specimens were obtained from patients with EC (age ranged from 29 to 66 years; mean age, $50.88 \pm 8.17$ years) at The Third Affiliated Hospital of Zhengzhou University from 2014 to 2017. According to the International Federation of Gynecology and Obstetrics (FIGO) classification of the International Union against Cancer (23), the study included a total of 32 stage I cases, 21 stage II cases, 24 stage III cases and 6 stage IV cases. In addition, there were 25 cases with lymph node metastasis (LNM) and 58 cases without LNM. In terms of histological grade, there were 22 cases of high differentiation (G1), 36 cases of moderate differentiation (G2), and 25 cases of low differentiation (G3). None of the patients included in the study underwent chemotherapy, hormone therapy or radiotherapy prior to surgery.

Immunohistochemistry. The specimens were fixed by $10 \%$ formaldehyde, paraffin-embedded and cut into $4-\mu \mathrm{m}$-thick sections. The sections were dried at $60^{\circ} \mathrm{C}$ for $1 \mathrm{~h}$ in a temperature-controlled incubator, conventionally dewaxed with xylene, dehydrated using gradient alcohol, and subsequently incubated in $3 \% \mathrm{H}_{2} \mathrm{O}_{2}$ (Sigma-Aldrich Chemical Company, St. Louis MO, USA) at $37^{\circ} \mathrm{C}$ for $30 \mathrm{~min}$. The sections were rinsed with phosphate-buffered saline (PBS) and placed in a $0.01 \mathrm{M}$ citric acid buffer solution for repairing, boiled at $95^{\circ} \mathrm{C}$ for $20 \mathrm{~min}$, rinsed with PBS once more, and allowed to reach room temperature. The sections were then blocked with normal goat serum at $37^{\circ} \mathrm{C}$ for $10 \mathrm{~min}$. Subsequently, the sections were supplemented with primary antibody mouse anti-hsa-MDM2 (ab38618, dilution ratio of 1:50; Abcam, Cambridge, MA, USA) at $4^{\circ} \mathrm{C}$ for $12 \mathrm{~h}$. After the sections were rinsed in PBS, they were incubated with the corresponding biotin-labeled goat anti-mouse secondary antibody (dilution ratio of 1:500; ab7067; Abcam) and were allowed to undergo a 10 -min reaction at room temperature. The sections were once again rinsed with PBS, and streptavidin labeled with horseradish peroxidase (S-A/HRP) was added to the sections and allowed to react at room temperature for $10 \mathrm{~min}$. The sections were colored using diaminobenzidine (DAB) coloration and were stored at room temperature for $8 \mathrm{~min}$. The sections were then rinsed under running water, stained using hematoxylin, dehydrated, cleared for transparency, mounted and observed under a light microscope (e100; Nikon, Tokyo, Japan). Three homolographic visual fields (x200) were randomly selected for each section, and Nikon image analysis software (Nikon Vision Co., Ltd., Tokyo, Japan) was applied to calculate the number of positive cells. Each field included 100 cells, and the percentage of positive cells to total cells was calculated as previously described (24). The percentage $>10 \%$ was considered as positive (+), otherwise as negative (-). As observed, MDM2 primarily stained the nuclei of the cancer cells, and the positive cells exhibited brownish yellow coloration. The immunohistochemical scoring criteria were the staining intensity of positive cell nuclei and the proportion of positive cells to total cells.

Cell culture and screening of CP-31398 concentration. The human EC cell lines, HEC-1-A, RL95-2, Ishikawa and KLE, were purchased from the Institute of Biochemistry and Cell Biology, Shanghai Institutes for Biological Sciences, Chinese Academy of Sciences (Shanghai, China). The cell lines were cultured in a $5 \% \mathrm{CO}_{2}$ incubator at $37^{\circ} \mathrm{C}$ with $10 \%$ Dulbecco's modified Eagle's medium(DMEM) containing $10 \%$ fetal bovine serum (FBS). The cells were treated with $0.25 \%$ trypsin at a 1:3 ratio and were then passaged. Third generation cells were collected using a cryopreservation tube, placed in a dimethyl sulfoxide (DMSO) solution and stored in liquid nitrogen. Some cells were inoculated in a 6-well plate for further culture. Reverse transcription-quantitative PCR (RT-qPCR) was conducted in order to detect the expression of MDM2 in each cell line, and two lines presenting with a higher expression were selected for use in follow-up experiments. CP-31398 was purchased from Shenzhen Neobioscience Co., Ltd. (Shenzhen, China) and was dissolved in DMSO (25-950-CQC; Beijing Tideradar Biomart Co., Ltd., Beijing, China); 4 different concentrations of CP-31398 $(1,2,4$ and $6 \mu \mathrm{g} / \mathrm{ml})$ were obtained. The screened cells were harvested in the logarithmic phase of growth and were digested, centrifuged at $4^{\circ} \mathrm{C}, 201 \mathrm{x}$ g, diluted to a solution of $1 \times 10^{5}$ cells $/ \mathrm{ml}$ with DMEM medium containing $10 \%$ FBS and were inoculated into a 96-well culture plate with $200 \mu \mathrm{l} /$ well. After being cultured in a $5 \% \mathrm{CO}_{2}$ incubator at $37^{\circ} \mathrm{C}$ for $24 \mathrm{~h}$, the liquid in the culture wells was replaced with $200 \mu \mathrm{l} /$ well of the 4 different prepared concentrations of CP-31398. CP-31398 (1\%) dissolved in DMSO was used as the control group and blank group, with 3 replicate wells set in each group. After being cultured in a $5 \% \mathrm{CO}_{2}$ incubator at $37^{\circ} \mathrm{C}$ for $24 \mathrm{~h}$, the liquid in the culture wells was removed, and the cells were rinsed with PBS. The original medium was replaced by $180 \mu \mathrm{l} /$ well serum-free medium, and $20 \mu \mathrm{l}$ of $5 \mathrm{mg} / \mathrm{ml}$ 3-(4,5-dimethylthiazol-2-yl)-2,5-diphenyltetrazolium bromide (MTT) solution was added. After the culture plates 
were incubated at $37^{\circ} \mathrm{C}$ for $4 \mathrm{~h}$ in the dark, the liquid in the culture wells was replaced with $150 \mu 1$ DMSO. The optical density (OD) was measured at a wavelength of $490 \mathrm{~nm}$, and the cell survival rate was calculated. The Karber method (25) was used to determine the $50 \%$ inhibitory concentration (IC50) of CP-31398. The survival rate of the EC cells was calculated according to the following formula: Drug OD/OD in the control group $\mathrm{x} 100 \%$. The Käber method formula was as follows: IgIC50 $=\mathrm{Xm}-\mathrm{I}[\mathrm{P}-(3-\mathrm{Pm}-\mathrm{Pn}) / 4]$, where 'Xm' represents the Ig maximum dose, 'I' indicates the Ig or maximum dose/near dose, 'P' represents the sum of the positive reaction rate, 'Pm' indicates the maximum positive reaction rate and 'Pn' refers to the minimum positive reaction rate.

Cell grouping and transfection. The two cell lines were divided into the following 6 groups: The blank group (no treatment), negative control (NC) group (transfected with NC empty plasmid), CP-31398 group (transfected with $2 \mu \mathrm{g} / \mathrm{ml}$ CP-31398), si-MDM2 group (transfected with siRNA-MDM2), CP-31398 + si-MDM2 group (treated

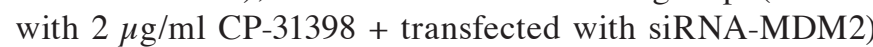
and CP-31398 + oe-MDM2 group (treated with $2 \mu \mathrm{g} / \mathrm{ml}$ CP-31398 + transfected with overexpression MDM2 plasmid). The cells were cultured for 3 days, the original medium was replaced with $2 \mu \mathrm{g} / \mathrm{ml} \mathrm{CP-31398}$ [Shenzhen Neobioscience Co., Ltd. (Shenzhen, China)], and the cells were collected following culture for $24 \mathrm{~h}$. EC cells in the logarithmic phase of growth were seeded in a 6-well plate, allowed to reach $30-50 \%$ cell confluence and transfected according to the instructions of the Lipofectamine 2000 transfection kit (Thermo Fisher Scientific, Waltham, MA, USA). The 100 pmol siRNA-MDM2 or oe-MDM2 and MDM2 NC sequences (sc-29394, purchased from Santa Cruz Biotechnology Co., Ltd., Shanghai, China) were diluted using $250 \mu \mathrm{l}$ serum-free medium Opti-MEM (31985-070; Gibco; Thermo Fisher Scientific, Inc.). Only forward strand shown: siMDM2, 5'-CCAGGAGAGUGACGACUAU-3'; siNC, 5'-CUGACGCGGAAUACUUCGAUU-3'. After they were mixed, the cells were incubated at room temperature for 5 min. Subsequently, $5 \mu 1$ Lipofectamine 2000 was diluted using $250 \mu \mathrm{l}$ serum-free medium Opti-MEM, and after they were mixed, the cells were incubated at room temperature for $5 \mathrm{~min}$. The above-mentioned two complexes were mixed evenly, incubated at room temperature for $20 \mathrm{~min}$, and subsequently added to the cell culture wells. The cells were placed in a $5 \% \mathrm{CO}_{2}$ incubator at $37^{\circ} \mathrm{C}$ for $6-8 \mathrm{~h}$ and were then cultured in complete medium for 24-48 h, as previously described (26).

$R T-q P C R$. Total RNA was extracted from the tissues manually using TRIzol reagent (15596026; Invitrogen; Thermo Fisher Scientific, Inc.). The concentration of the extracted RNA was detected using an ultraviolet spectrophotometer. According to the instructions provided with the PrimeScript RT kit (RR014A; Takara Biotechnology Ltd., Beijing, China), RNA was reverse transcribed into cDNA, and the total system was $10 \mu \mathrm{l}$. The reaction conditions were as follows: Reverse transcription at $37^{\circ} \mathrm{C}$ for $15 \mathrm{~min} 3$ times, and reverse transcriptase inactivation reaction at $85^{\circ} \mathrm{C}$ for $5 \mathrm{sec}$. The PCR reaction was carried out with an appropriate amount of cDNA as the template. All primers were designed using Primer 5.0 software and were synthesized by the Nanjing Genscript Technology Co., Ltd. (Nanjing, China); the primer sequences are presented in Table I. RT-qPCR was carried out according to the instructions provided with the PCR kit (KR011A1; Beijing Tiangen Biotech Co., Ltd., Beijing, China). The reaction conditions included pre-denaturation at $95^{\circ} \mathrm{C}$ for $4 \mathrm{~min}, 40$ cycles of denaturation at $95^{\circ} \mathrm{C}$ for $40 \mathrm{ec}$, annealing at $57^{\circ} \mathrm{C}$ for $40 \mathrm{sec}$, extension at $72^{\circ} \mathrm{C}$ for $40 \mathrm{sec}$, extension at $72^{\circ} \mathrm{C}$ for $10 \mathrm{~min}$, and finally, annealing at $4^{\circ} \mathrm{C}$ for $5 \mathrm{~min}$. The reaction system was as follows: SYBR Premix Ex Taq ${ }^{\mathrm{TM}}$ II $10 \mu$ l, PCR forward primer $(10 \mu \mathrm{M}) 0.4 \mu \mathrm{l}$, PCR reverse primer $(10 \mu \mathrm{M}) 0.4 \mu \mathrm{l}$, DNA template $(2 \mu \mathrm{l})$ and sterilized distilled water $(7.2 \mu \mathrm{l})$. With glyceraldehyde-3-phosphate dehydrogenase (GAPDH) acting as the reference gene, the expression of MDM2, p53, p21, Bad, Bax, Bcl-2, Cyt-c, caspase-3, Cox-2, MMP-2 and MMP-9 was measured using the $2^{-\Delta \Delta \mathrm{Cq}}$ method (27). $\Delta \mathrm{Ct}=\mathrm{Ct}_{\text {target }}$ gene $-\mathrm{Ct}_{\mathrm{GAPDH}}, \Delta \Delta \mathrm{CT}=\Delta \mathrm{Ct}_{\text {experiment group }}-\Delta \mathrm{Ct}_{\text {control group }}$, and the relative transcriptional level of target gene mRNA was $2^{-\Delta \Delta \mathrm{Cq}}(28)$. The gene expression in each group was compared. The method is also suitable for cell experiments $(29,30)$.

Western blot analysis. Following $48 \mathrm{~h}$ of cellular transfection, the cells were collected, rinsed 3 times with cold PBS (AR0030; Boster Biological Technology Co., Ltd., Wuhan, China), supplemented with radioimmunoprecipitation assay (RIPA) protein lysate (PS0013; Reagan Biological Technology Co., Ltd., Beijing, China), and lysed on ice for $10 \mathrm{~min}$, and the cellular protein was then obtained. According to the instructions provided with the bicinchoninic acid (BCA) kit (23250; Thermo Fisher Scientific, Inc., Shanghai, China), the total protein content was determined, packaged and stored at $-80^{\circ} \mathrm{C}$ in a refrigerator. Subsequently, $50 \mu \mathrm{g}$ of protein were extracted from each group, supplemented with a protein denaturation agent (38249090; Shanghai Shisheng Sibas Advanced Technology Co., Ltd., China), boiled for $10 \mathrm{~min}$ for denaturalization, and then separated using $12 \%$ sodium dodecyl sulfate polyacrylamide gel electrophoresis (SDS-PAGE). Following electrophoresis, the protein was transferred from the SDS-PAGE gel to a nitrocellulose membrane by electrophoretic transfer. The nitrocellulose membrane was kept for one night at $4^{\circ} \mathrm{C}$ in $10 \%$ poly (butylene succinate-co-terephthalate) (PBST) containing skim milk powder and was rinsed with PBST 3 times (5 min each). Primary antibodies, including rabbit anti-human MDM2 (ab38618; dilution ratio, 1:1,000), rabbit anti-human wild-type p53 (ab26; dilution ratio, 1:1,000) and p21 (ab109520; dilution ratio, 1:1,000), rabbit anti-human Bad (ab32445; dilution ratio, 1:2,000), BCL2-Associated X (Bax; ab32503; dilution ratio, 1:1,000), B-cell lymphoma-2 (Bcl-2; ab32124; dilution ratio, 1:1,000), cytochrome $c$ (Cyt-c; ab133504; dilution ratio, 1:5,000), caspase-3 (ab13847; dilution ratio, 1:500), cyclooxygenase 2 (Cox-2; ab52237; dilution ratio, 1:500), matrix metalloproteinase (MMP)-2 (ab92536; dilution ratio, 1:1,000) and MMP-9 (ab73734; dilution ratio, 1:1,000) were added followed by incubation overnight at $4^{\circ} \mathrm{C}$. The aforementioned antibodies were purchased from Abcam Inc. The secondary antibody goat anti-rabbit labeled by horseradish peroxidase immunoglobulin $\mathrm{G}$ ( $\operatorname{IgG}$ ) (ab6721; dilution ratio, 1:1,000) was incubated at room temperature for $120 \mathrm{~min}$. The membrane was rinsed with tris-buffered saline-tween (TBST) buffer 3 times. Enhanced chemiluminescence (ECL) reagent 
(36208ES60; Amersham Life Sciences, Chicago, IL, USA) was used to carry out the luminescence reaction, press, develop, fix and develop the images in the imaging analyzer (ImageReader; Bio-Rad Laboratories, Inc., Hercules, CA, USA). Quantity One software was used to analyze the band gray value, the relative expression of the target gene, presenting as the ratio of the gray value of the internal reference band with the band of the target gene. Experiments for each sample were repeated 3 times.

Terminal deoxynucleotidyl transferase-mediated dUTP nick-end labeling (TUNEL) assay. Cells in the logarithmic phase of growth were inoculated in a 96-well plate at $1 \times 10^{4}$ cells/well, and $50 \mu \mathrm{l}$ TUNEL reaction solution was added for $60 \mathrm{~min}$ after the cells were cultured overnight. After rinsing, the cells were supplemented with conversion solution and incubated, stained with DAB for $30 \mathrm{~min}$, and observed under a light microscope (e100; Nikon). Cells with brown granules in their nuclei were regarded as positive cells, namely, apoptotic cells. Apoptotic Index (AI) = apoptotic cells/total cells. The positive rate of apoptotic cells $(\%)=($ the number of apoptotic cells per 1,000 tumor cells/1,000) x100\%.

Flow cytometry. The Annexin V-fluorescein isothiocyanate (FITC)/propidium iodide (PI) double staining method was used for cell apoptosis. Following $48 \mathrm{~h}$ of transfection, the cells were treated with $0.25 \%$ trypsin [without ethylenediaminetetraacetic acid (EDTA)], and the cells were collected in the flow tube, centrifuged at $4^{\circ} \mathrm{C}$ at $201 \mathrm{x}$ g with the supernatant discarded. The cells were rinsed with cold PBS 3 times, and the supernatant was discarded. According to the instructions provided with the Annexin V-FITC kit (purchased from Roche, Basel, Switzerland), Annexin V-FITC/PI dying buffer was prepared by mixing Annexin V-FITC, PI, 4-(2-hydroxyethyl)-1-piperazineethanesulfonic acid (HEPES) buffer solution at the proportion of 1:2:50. The cells were incubated at room temperature for $15 \mathrm{~min}$, and $1 \mathrm{ml}$ HEPES buffer solution (PB180325; Procell, Wuhan, China) was added, followed by shaking and evenly mixing the solution. The fluorescence of FITC and PI was detected by 525 and $620 \mathrm{~nm}$ bandpass filters at a wavelength of $488 \mathrm{~nm}$ by using a flow cytometer (LSR-II; BD Biosciences, Franklin Lakes, NJ, USA), and apoptosis was detected. The experiment was repeated 3 times.

Scratch test. Following $48 \mathrm{~h}$ of transfection, cells in the logarithmic phase of growth were inoculated in a 6-well plate at a density of $1 \times 10^{6}$ cells/well and were cultured in a $5 \% \mathrm{CO}_{2}$ incubator at $37^{\circ} \mathrm{C}$. The cells were allowed to reach a confluence of approximately $95 \%$, and vertical linear scratches were made in the 6 -well plate using a $20 \mu 1$ micro pipette head. The exfoliated cells were removed using D-Hanks solution, and then the cells were cultured in a serum-free medium. At 0 and $24 \mathrm{~h}$ post-scratching, 3 fields were selected and photographed by using a phase contrast microscope (x100 magnification, TE2000; Nikon) to compare the scratch-healing differences among groups, which represent cell migration and healing abilities. Scratch healing rate $(\%)=($ scratch width at $0 \mathrm{~h}$ - scratch width at $24 \mathrm{~h}$ )/scratch width at $0 \mathrm{~h} \times 100 \%$.

Transwell assay. Cell invasion experiments were performed using a Transwell chamber (BD Biosciences), containing
Table I. Primer sequences of MDM2, p53, p21, Bad, Bax, Cyt-c, caspase-3, Cox-2, MMP-2, MMP-9 and GAPDH.

\begin{tabular}{|c|c|}
\hline Genes & Primer sequence $\left(5^{\prime}-3^{\prime}\right)$ \\
\hline MDM2 & $\begin{array}{l}\text { F: GAAAGATGGAGCAAG } \\
\text { R: GAGGTGGTTACAGCA }\end{array}$ \\
\hline p53 & $\begin{array}{l}\text { F: GTCATCTTCTGTCCCTTCCC } \\
\text { R: ACCTCAGGCGGC TCATAG }\end{array}$ \\
\hline $\mathrm{p} 21$ & $\begin{array}{l}\text { F: GCG ATG GAA CTT CGACTT TGT } \\
\text { R: GGG CTT CCT CTT GGA GAAGAT }\end{array}$ \\
\hline Bad & $\begin{array}{l}\text { F: CCCAGAGTTTGAGCCGAGTG } \\
\text { R: CCCATCCCTTCGTCGTCCT }\end{array}$ \\
\hline Bax & $\begin{array}{l}\text { F: GCTTCAGGGTTTCATCCAG } \\
\text { R: GGCGGCAATCATCCTCTG }\end{array}$ \\
\hline $\mathrm{Bcl}-2$ & $\begin{array}{l}\text { F: TACTTAAAAAATACAACATCACAG } \\
\text { R: GGAACACTTGATTCTGGTG }\end{array}$ \\
\hline Cyt-c & $\begin{array}{l}\text { F: GATCACCCCCAGCCTCCCTTATC } \\
\text { R: AAAATAGAGAATTTAAAAGGCCTAAC }\end{array}$ \\
\hline Caspase-3 & $\begin{array}{l}\text { F: CTGGACTGTGGCATTGAGAC } \\
\text { R: ACAAAGCGACTGGATGAACC }\end{array}$ \\
\hline Cox-2 & $\begin{array}{l}\text { F: TTCCAGATCCAGAGCTCATTAAA } \\
\text { R: CCGGAGCGG GAAGAACT }\end{array}$ \\
\hline MMP-2 & $\begin{array}{l}\text { F: CCGCAGTGACGGAAAGATGT } \\
\text { R: GCCACGAGGAACAGGCTGTA }\end{array}$ \\
\hline MMP-9 & $\begin{array}{l}\text { F: ACGCACGACGTCTTCCAGTAC } \\
\text { R: ACCTGGTTCAACTCACTCCGG }\end{array}$ \\
\hline GAPDH & $\begin{array}{l}\text { F: CAACTACATGGTTTACATGTTC } \\
\text { R: GCCAGTGGACTCCACGAC }\end{array}$ \\
\hline
\end{tabular}

MDM2, murine double minute 2; Bcl-2, B-cell lymphoma-2; Bax, BCL2-associated X; Cyt-c, cytochrome $c$; Cox-2, cyclooxygenase 2; MMP, matrix metalloproteinase; GAPDH, glyceraldehyde-3-phosphate dehydrogenase; $F$, forward; $R$, reverse.

$12 \mathrm{~mol} / 1$ polycarbonate membrane per well. Extracellular matrix (ECM) was diluted in serum-free DMEM at a proportion of $1: 7$ and placed in an incubator at $37^{\circ} \mathrm{C}$ for 15 min to solidify. The cells were then rinsed with PBS 2 times, treated with $0.25 \%$ trypsin, and centrifuged at room temperature at $201 \mathrm{x} \mathrm{g}$, and the cell concentration was adjusted to $2.5 \times 10^{4}$ cells $/ \mathrm{ml}$ with serum-free phenolred free DMEM (high glucose). The lower chamber of the Transwell was filled with $200 \mu 1$ serum-free medium, while the upper chamber was filled with cell suspensions from each group at $1 \times 10^{4}$ and $200 \mu 1$ serum-free medium (DMEM, adding $5 \mathrm{U} / \mathrm{l}$ insulin). Five duplicate wells were set in each group. The Transwell chamber was cultured in a $5 \% \mathrm{CO}_{2}$ incubator at $37^{\circ} \mathrm{C}$ with $95 \%$ humidity in the air for $48 \mathrm{~h}$. The polycarbonate membrane was then cut off, and the bottom of the membrane was fixed with acetone at $4^{\circ} \mathrm{C}$ for $5 \mathrm{~min}$ and dyed with $0.1 \%$ crystal violet (G1063; Solarbio, Beijing, China) at room temperature for $1 \mathrm{~h}$. The number of cells in the top, bottom, middle, left and right visual fields of the polycarbonate membrane was counted using a microscope (TE2000; Nikon) 


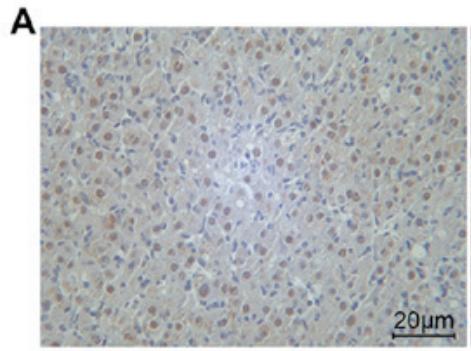

Adjacent normal tissues

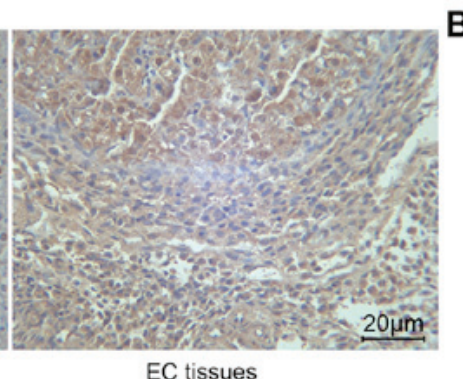

EC tissues

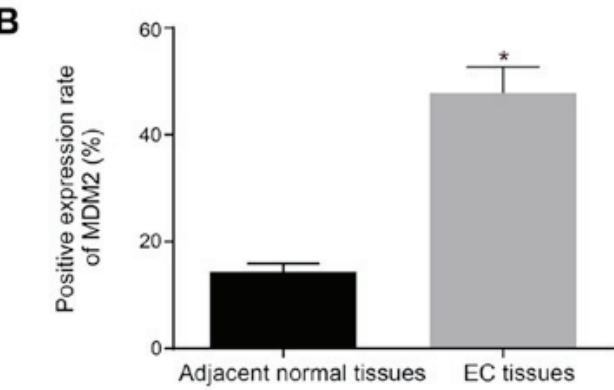

Figure 1. EC tissues exhibit an increased MDM2 expression (magnification, $\mathrm{x} 200$ ). (A) Immunohistochemical staining of MDM2 protein in EC tissues and adjacent normal tissues; (B) positive expression of MDM2 protein in EC tissues and adjacent normal tissues; ${ }^{*} \mathrm{P}<0.05$ vs. the adjacent normal tissues; $\mathrm{n}=83$. The statistical data are presented as the means \pm standard deviation and analyzed using a paired t-test. Scale bar, $25 \mu \mathrm{m}$. MDM2, murine double minute 2; EC, endometrial cancer.

with a 20X objective view field, and the average number was calculated and recorded.

Statistical analysis. Statistical analyses were performed using the SPSS 21.0 statistical software (IBM Corp. Armonk, New York, USA). Measurement data are presented as the means \pm standard deviation. Initially, the normality and homogeneity of variance were tested by Kolmogorov-Smirnov (KS) test and Levene's test. Comparisons between 2 groups of data with normal distribution and even variance were analyzed using a paired t-test or an independent samples t-test. Comparisons among multiple groups were analyzed by one-way analysis of variance (ANOVA) followed by a Tukey's post hoc test. A value of $\mathrm{P}<0.05$ was considered to indicate a statistically significant difference.

\section{Results}

Positive expression rate of MDM2 is higher in EC tissues. Immunohistochemistry was applied to detect the positive expression rate of MDM2, and the results revealed that (Fig. 1) the positive protein expression of MDM2 was observed as brownish yellow granules in the nuclei of the cells. Compared with the adjacent normal tissues, the EC tissues exhibited a significantly increased positive protein expression of MDM2 $(\mathrm{P}<0.05)$.

Expression of MDM2, MMP-2 and MMP-9 is increased in EC tissues. The expression levels of MDM2, MMP-2 and MMP-9 were detected in EC tissues and adjacent normal tissues by RT-qPCR. The results revealed that the expression of MDM2, MMP-2 and MMP-9 in the EC tissues was significantly higher than that in the adjacent normal tissues (Fig. 2). By means of the analysis of clinical and pathological data, we found that the expression of MDM2, MMP-2 and MMP-9 was closely related to the pathological grade and lymph node metastasis in patients with EC $(\mathrm{P}<0.05)$; however, no association was observed with the patient's age or tumor size and histological type (P>0.05; Table II). The expression of MDM2, MMP-2 and MMP-9 was significantly increased in the patients with stage III + IV disease compared to those with stage I + II disease. The expression of MDM2, MMP-2 and MMP-9 in patients with LNM was also increased significantly compared to the expression in patients without LNM $(\mathrm{P}<0.05)$.

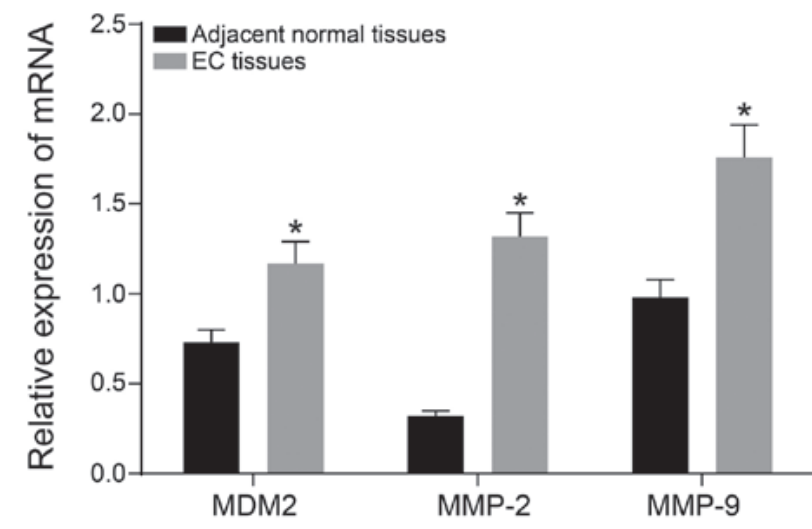

Figure 2. mRNA expression of MDM2, MMP-2 and MMP-9 in EC tissues is higher than that in adjacent normal tissues. ${ }^{*} \mathrm{P}<0.05$ vs. the normal group; $\mathrm{n}=83$. The statistical data are presented as the means \pm standard deviation and analyzed using a paired t-test. EC, endometrial cancer; MDM2, murine double minute 2; MMP, matrix metalloproteinase.

RL95-2 and KLE cell lines are selected for further experiments. To select the most suitable cell lines for our study, MDM2 expression was examined in 4 different EC cell lines by RT-qPCR (Fig. 3). The results revealed that the expression levels of MDM2 in the RL95-2 and KLE EC cell lines were significantly higher than those in the HEC-1-A and Ishikawa cell lines (all $\mathrm{P}<0.05$ ). Therefore, the RL95-2 and KLE cell lines were screened for use in subsequent experiments.

CP-31398 concentration is set at $2 \mu \mathrm{g} / \mathrm{ml}$. Subsequently, the most suitable concentration of CP-31398 was also determined. Following treatment of the RL95-2 and KLE cell lines with 4 concentrations $(1,2,4$ and $6 \mathrm{~g} / \mathrm{ml})$ of CP-31398 for $24 \mathrm{~h}$, the results of MTT assay revealed that the cell activity decreased gradually with the increasing concentrations of CP-31398 (Fig. 4A); the inhibitory effect of CP-31398 on RL95-2 and KLE cell viability amplified with increasing concentrations (Fig. 4B). The IC50 value of CP-31398 was calculated to be $2.74 \mu \mathrm{g} / \mathrm{ml}$ according to the Käber method; thus, the concentration of CP-31398 used in the following experiments was $2 \mu \mathrm{g} / \mathrm{ml}$.

$C P-31398$ decreased the $M R N A$ expression of MDM2, Bcl-2, Cox-2, MMP-2 and MMP-9, but increases that of p53, p21, Bad, Bax, Cyt-c and caspase-3 in EC cells. To examine the 
Table II. Association between the mRNA expression of MDM2, MMP-2 and MMP-9 in EC and clinicopathological data.

\begin{tabular}{|c|c|c|c|c|c|c|c|}
\hline Clinicopathological indicator & $\mathrm{n}$ & MDM2 & P-value & MMP-2 & P-value & MMP-9 & P-value \\
\hline Age (years) & & & 0.102 & & 0.24 & & 0.397 \\
\hline$\leq 45$ & 20 & $1.13 \pm 0.14$ & & $1.29 \pm 0.10$ & & $1.73 \pm 0.22$ & \\
\hline$>45$ & 63 & $1.18 \pm 0.11$ & & $1.33 \pm 0.14$ & & $1.77 \pm 0.17$ & \\
\hline Pathological grading & & & $<0.001$ & & $<0.001$ & & $<0.001$ \\
\hline $\mathrm{I}+\mathrm{II}$ & 53 & $1.12 \pm 0.10$ & & $1.27 \pm 0.12$ & & $1.70 \pm 0.17$ & \\
\hline III+IV & 30 & $1.26 \pm 0.10$ & & $1.41 \pm 0.10$ & & $1.87 \pm 0.13$ & \\
\hline Lymph node metastasis & & & 0.014 & & $<0.001$ & & 0.021 \\
\hline Metastasis & 25 & $1.22 \pm 0.11$ & & $1.40 \pm 0.11$ & & $1.83 \pm 0.17$ & \\
\hline Non-metastasis & 58 & $1.15 \pm 0.12$ & & $1.29 \pm 0.13$ & & $1.73 \pm 0.18$ & \\
\hline Tumor size $(\mathrm{cm})$ & & & 0.455 & & 0.095 & & 0.089 \\
\hline$\leq 6$ & 49 & $1.16 \pm 0.14$ & & $1.30 \pm 0.11$ & & $1.73 \pm 0.19$ & \\
\hline$>6$ & 34 & $1.18 \pm 0.08$ & & $1.35 \pm 0.16$ & & $1.80 \pm 0.17$ & \\
\hline Histological type & & & 0.496 & & 0.092 & & 0.145 \\
\hline High differentiation & 22 & $1.19 \pm 0.11$ & & $1.35 \pm 0.09$ & & $1.70 \pm 0.19$ & \\
\hline Moderate differentiation & 36 & $1.17 \pm 0.13$ & & $1.29 \pm 0.12$ & & $1.76 \pm 0.20$ & \\
\hline Low differentiation & 25 & $1.15 \pm 0.11$ & & $1.33 \pm 0.09$ & & $1.81 \pm 0.19$ & \\
\hline
\end{tabular}

Data comparisons between 2 groups was analyzed by an independent samples t-test and data comparison among multiple groups by one-way analysis of variance followed by a Tukey's post hoc test. MDM2, murine double minute 2; MMP, matrix metalloproteinase; EC, endometrial cancer.

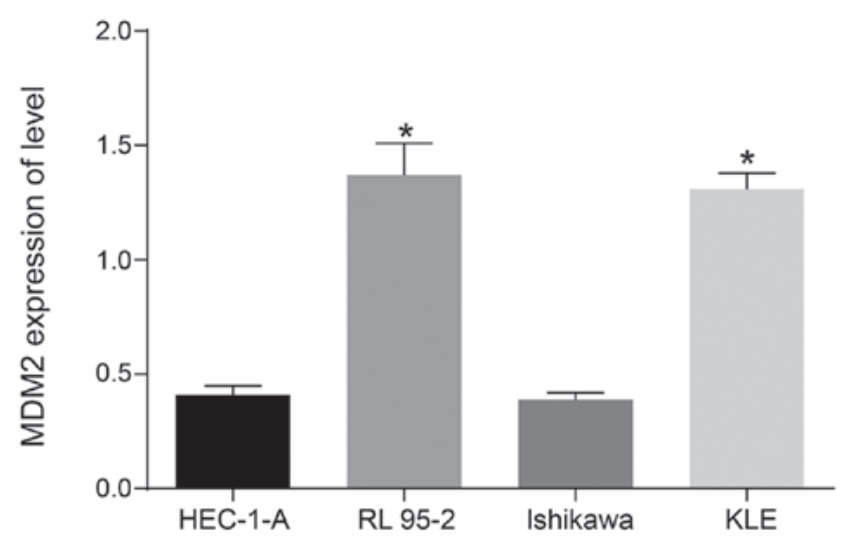

Figure 3. RL95-2 and KLE cell lines have a higher MDM2 expression than the HEC-1-A and Ishikawa cell lines. ${ }^{*} \mathrm{P}<0.05$ vs. HEC-1-A and Ishikawa cell lines. The statistical data are presented as the means \pm standard deviation and analyzed using one-way ANOVA followed by a Tukey's post hoc test. The experiment was repeated 3 times. EC, endometrial cancer.

effect of CP-31398 and MDM2 in EC, some related factors were assessed. The results of RT-qPCR revealed (Fig. 5) that the CP-3139, si-MDM2 and CP-31398 + si-MDM2 groups exhibited decreased mRNA expression levels of MDM2, Bcl-2, Cox-2, MMP-2 and MMP-9, and increased mRNA expression levels of p53, p21, Bad, Bax, Cyt-c and caspase-3 in the RL95-2 and KLE cells, however, the CP-31398 + oe-MDM2 group had no significant difference $(\mathrm{P}>0.05)$ compared to the blank and $\mathrm{NC}$ groups (all $\mathrm{P}<0.05)$. Compared with the CP-31398 group, the CP-31398 + si-MDM2 group exhibited decreased mRNA expression levels of MDM2, Bcl-2, Cox-2, MMP-2 and MMP-9 and increased mRNA expression levels of p53, p21, Bad, Bax,
Cyt-c and caspase-3 (all $\mathrm{P}<0.05$ ). From the above-mentioned results, it was suggested that $\mathrm{CP}-31398$ can elevate the mRNA expression of p53, p21, Bad, Bax, Cyt-c and caspase-3, while it can decrease that of Bcl-2, Cox-2, MMP-2 and MMP-9 by downregulating MDM2 expression.

CP-31398 decreases the protein levels of MDM2, Bcl-2, Cox-2, $M M P-2$ and MMP-9. but increases those of p53, p21, Bad, Bax, Cyt-c and caspase-3 in EC cells. The results of western blot analysis (Fig. 6) revealed that the CP-3139, si-MDM2 and CP-31398 + si-MDM2 groups exhibited decreased protein levels of MDM2, Bcl-2, Cox-2, MMP-2 and MMP-9, and increased levels of p53, p21, Bad, Bax, Cyt-c and caspase-3 in the RL95-2 and KLE cells. By contrast, the CP-31398 + oe-MDM2 group exhibited no significant difference $(\mathrm{P}>0.05)$ compared to the blank and NC groups (all $\mathrm{P}<0.05$ ). Compared with the $\mathrm{CP}-31398$ group, the CP-31398 + si-MDM2 group exhibited decreased protein levels of MDM2, Bcl-2, Cox-2, MMP-2 and MMP-9, and increased levels of P53, P21, Bad, Bax, Cyt-c and caspase-3 (all $\mathrm{P}<0.05)$. The above-mentioned findings demonstrate that CP-31398 can elevate the protein levels of p53, p21, Bad, Bax, Cyt-c and caspase-3, while it can decrease those of Bcl-2, Cox-2, MMP-2 and MMP-9 by downregulating MDM2.

CP-31398 promotes EC cell apoptosis by inhibiting MDM2 expression. The results of TUNEL staining (Fig. 7) indicated that the CP-31398, si-MDM2 and CP-31398 + si-MDM2 groups exhibited increased cell apoptosis, pyknosis of nuclei, and different shades of brown in RL95-2 and KLE cells $(\mathrm{P}<0.05)$, whereas the $\mathrm{CP}-31398+$ oe-MDM2 group exhibited no significant difference $(\mathrm{P}>0.05)$ compared to the blank and NC groups. Compared with the CP-31398 group, the 
A

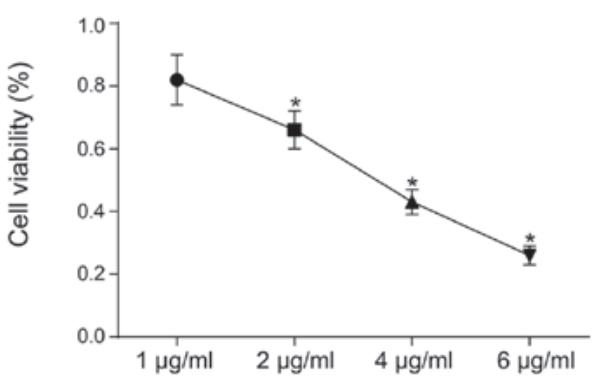

C

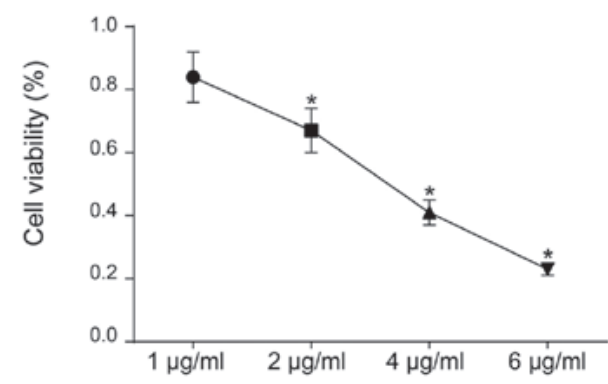

B

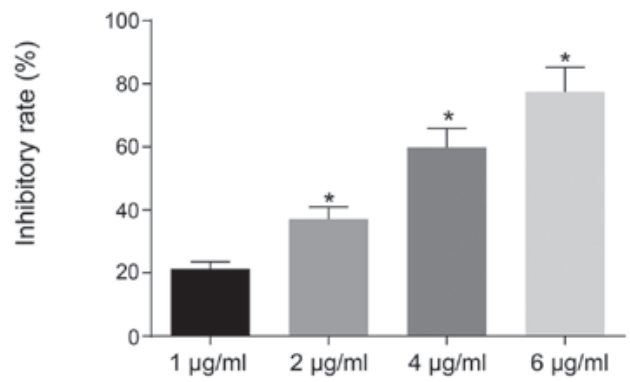

D

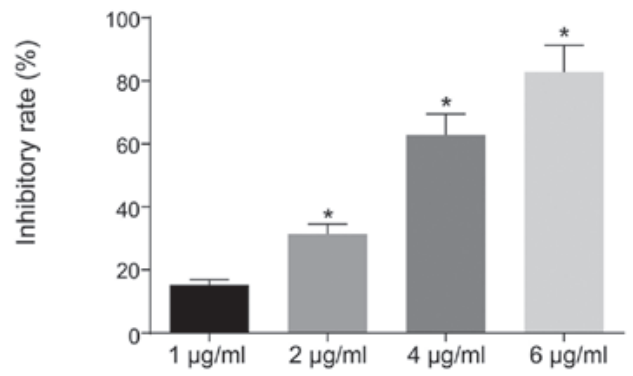

Figure 4. CP-31398 concentration is set at $2 \mu \mathrm{g} / \mathrm{ml}$. (A) Detection of RL95-2 cell activity; (B) detection of RL95-2 cell inhibition rate; (C) detection of KLE cell activity; (D) detection of KLE cell inhibition rate; "P $<0.05$ vs. the control group $(1 \mathrm{~g} / \mathrm{ml})$. The statistical data are presented as the means \pm standard deviation and were analyzed using one-way ANOVA followed by a Tukey's post hoc test. The experiment was repeated 3 times.

A RL95-2

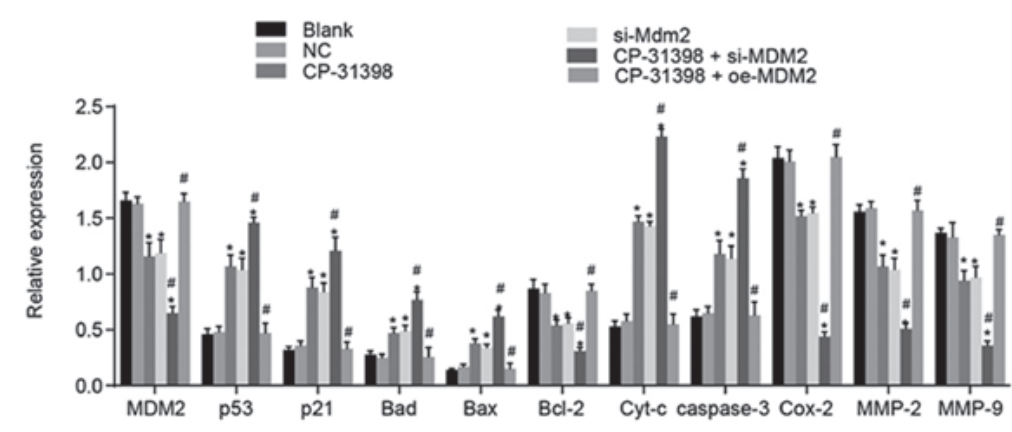

B KLE

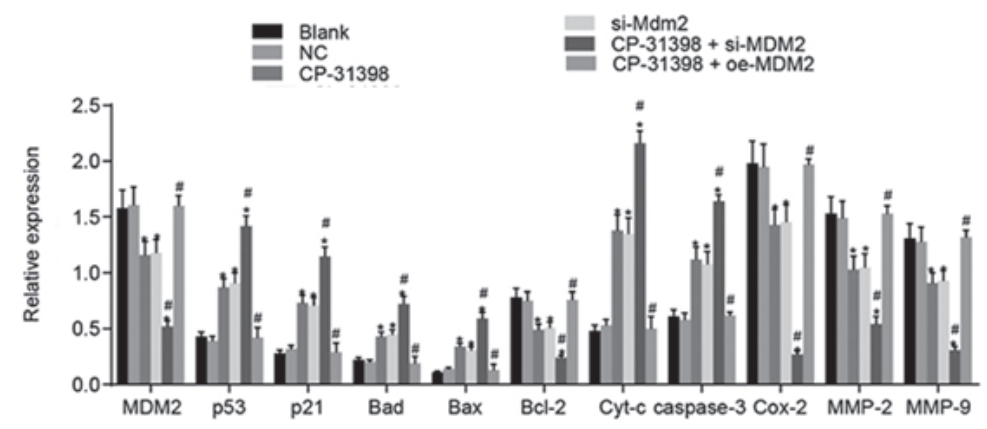

Figure 5. mRNA expression of MDM2, Bcl-2, Cox-2, MMP-2 and MMP-9 is decreased, but that of p53, p21, Bad, Bax, Cyt-c and caspase-3 is increased in EC cells treated with CP-31398 and si-MDM2. (A) mRNA expression of MDM2, Bcl-2, Cox-2, MMP-2, MMP-9, p53, p21, Bad, Bax, Cyt-c and caspase-3 in RL95-2 cells; (B) mRNA expression of MDM2, Bcl-2, Cox-2, MMP-2, MMP-9, p53, p21, Bad, Bax, Cyt-c and caspase-3 in KLE cells; "P<0.05 vs. the blank and NC groups; ${ }^{\prime} \mathrm{P}<0.05$ vs. the CP-31398 group. The statistical data are presented as the means \pm standard deviation and were analyzed using one-way ANOVA followed by a Tukey's post hoc test. The experiment was repeated 3 times. MDM2, murine double minute 2; Bcl-2, B-cell lymphoma-2; Bax, BCL2-associated X; Cyt-c, cytochrome $c$; Cox-2, cyclooxygenase 2; MMP, matrix metalloproteinase.

CP-31398 + si-MDM2 group exhibited increased apoptosis $(\mathrm{P}<0.05)$. These results indicated that $\mathrm{CP}-31398$ promoted the apoptosis of EC cells by downregulating the expression of MDM2. 
A

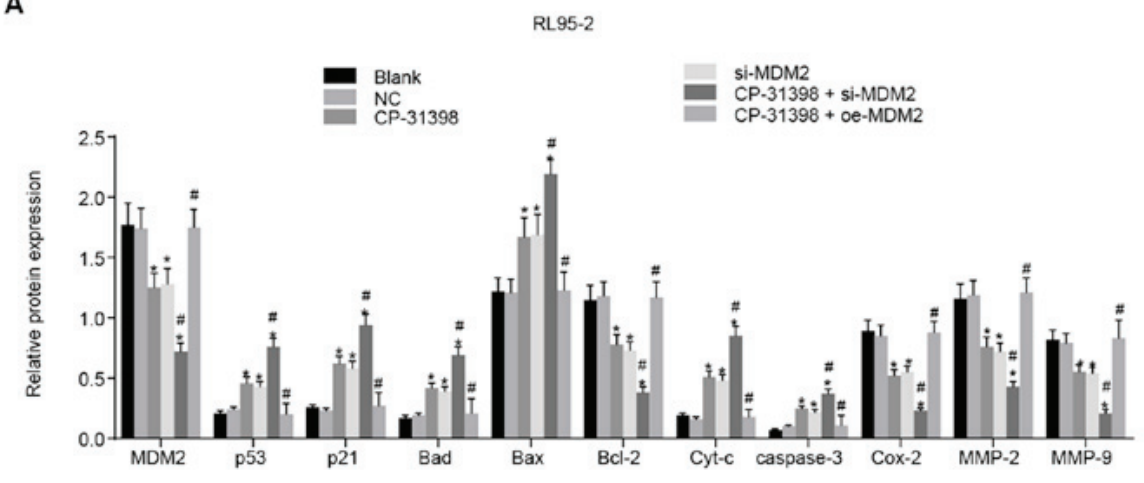

C

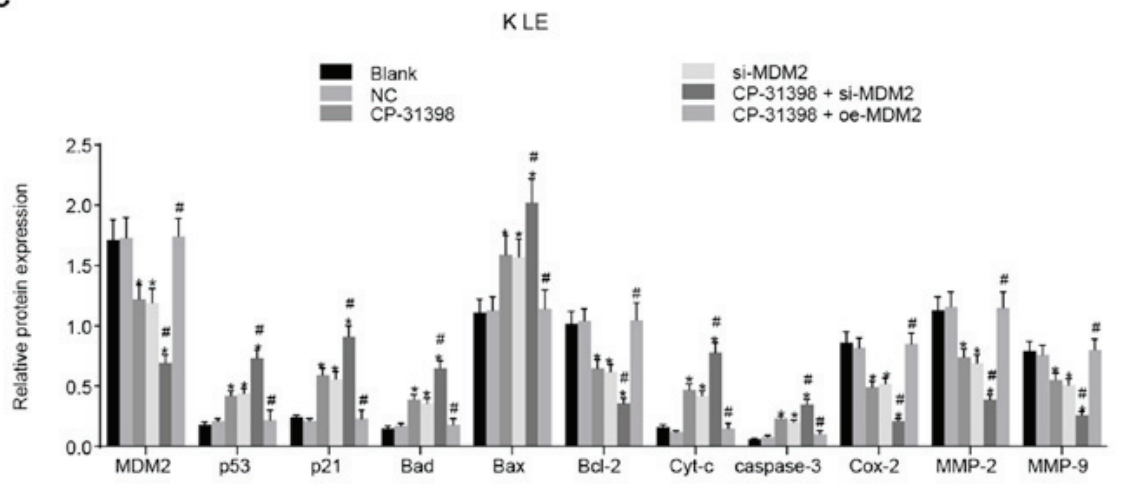

B

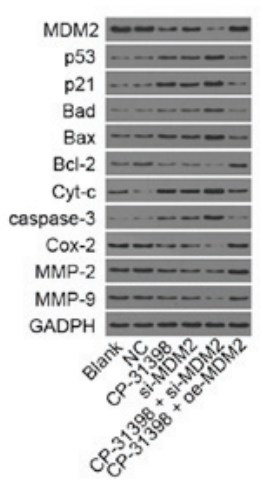

D

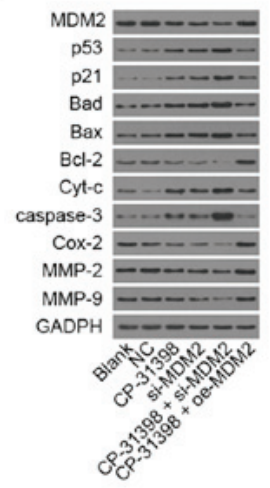

Figure 6. Protein levels of MDM2, Bcl-2, Cox-2, MMP-2 and MMP-9 are decreased, but those of p53, p21, Bad, Bax, Cyt-c and caspase-3 are increased in EC cells treated with CP-31398 and si-MDM2. (A) The protein level of MDM2, Bcl-2, Cox-2, MMP-2, MMP-9, p53, p21, Bad, Bax, Cyt-c and caspase-3 in RL95-2 cells; (B) the gray value of MDM2, Bcl-2, Cox-2, MMP-2, MMP-9, p53, p21, Bad, Bax, Cyt-c and caspase-3 in RL95-2 cells; (C) the protein levels of MDM2, Bcl-2, Cox-2, MMP-2, MMP-9, p53, p21, Bad, Bax, Cyt-c and caspase-3 in KLE cells; (D) the gray value of MDM2, Bcl-2, Cox-2, MMP-2, MMP-9, p53, p21, Bad, Bax, Cyt-c and caspase-3 in KLE cells; "P<0.05 vs. the blank and NC groups; ${ }^{*} \mathrm{P}<0.05$ vs. the CP-31398 group. The statistical data are presented as the means \pm standard deviation and were analyzed using one-way ANOVA followed by a Tukey's post hoc test. The experiment was repeated 3 times. MDM2, murine double minute 2; Bcl-2, B-cell lymphoma-2; Bax, BCL2-associated X; Cyt-c, cytochrome $c$; Cox-2, cyclooxygenase 2; MMP, matrix metalloproteinase.

A
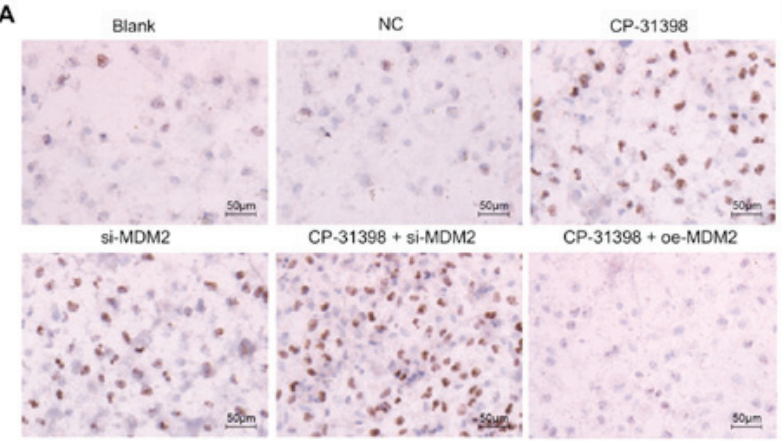

C

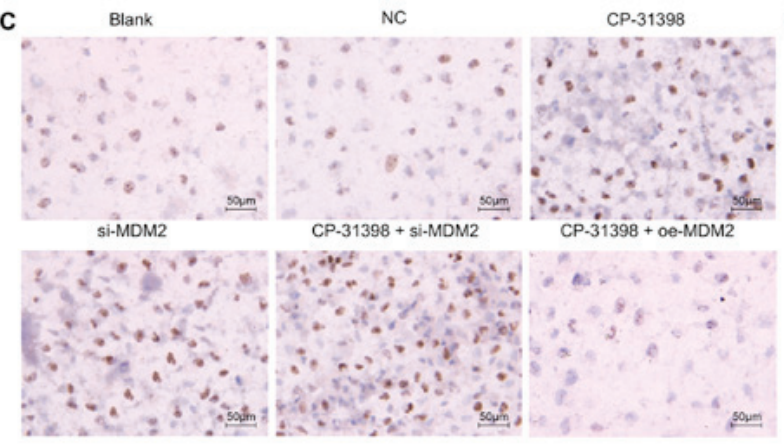

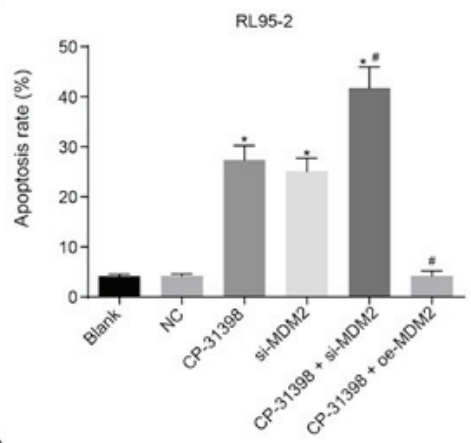

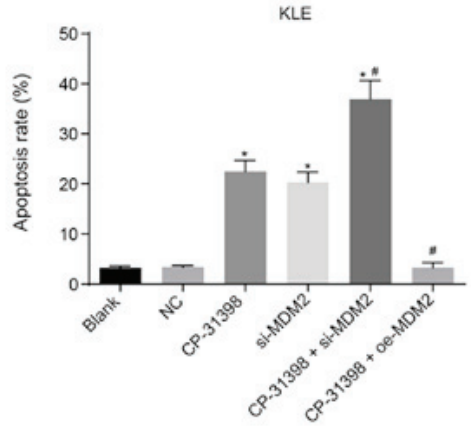

Figure 7. The cell apoptotic rate is higher in EC cells treated with CP-31398 and si-MDM2. (A) TUNEL staining results of RL95-2 cell (magnification, x200); (B) RL95-2 cell apoptotic rate; (C) TUNEL staining results of KLE cell (magnification, x200); (D) KLE cell apoptotic rate; ${ }^{\prime} \mathrm{P}<0.05$ vs. the blank and NC groups; ${ }^{*} \mathrm{P}<0.05$ vs. the CP-31398 group. The statistical data are presented as the means \pm standard deviation and were analyzed using one-way ANOVA followed by a Tukey's post hoc test. The experiment was repeated 3 times; TUNEL, TdT-mediated dUTP-biotin nick end-labeling; EC, endometrial cancer. 
A
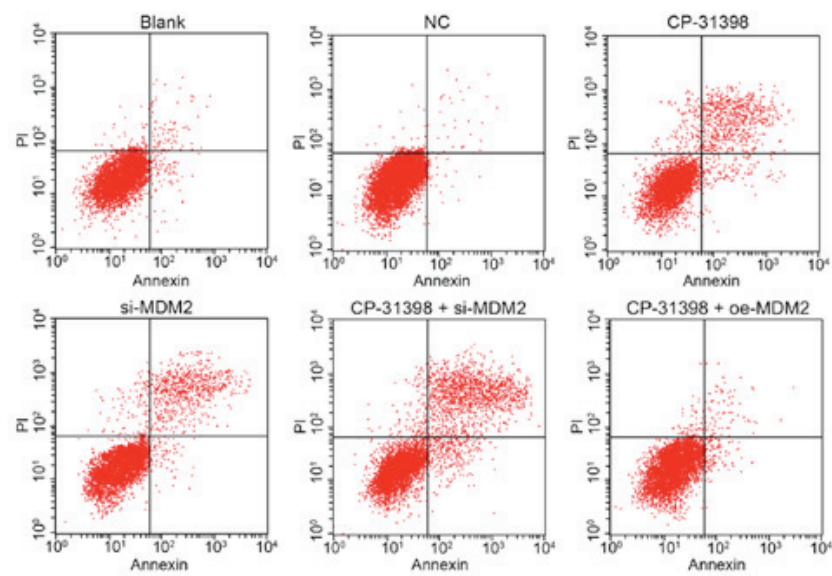

B
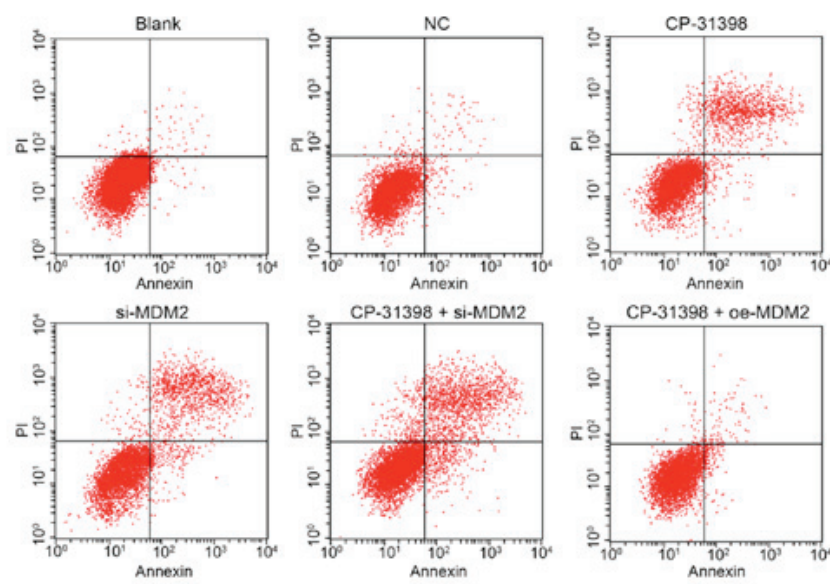
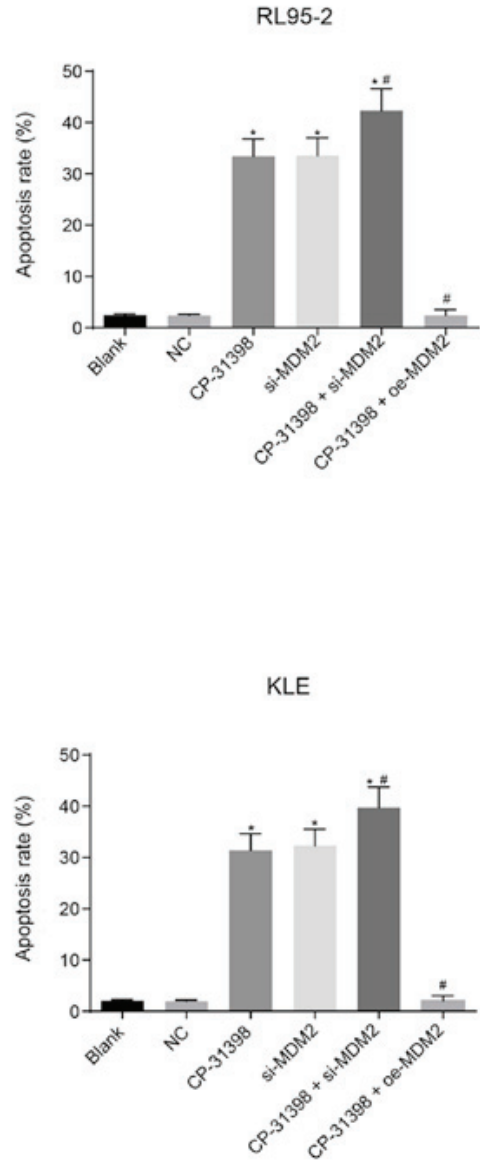

Figure 8. The cell apoptotic rate is increased in EC cells treated with CP-31398 and si-MDM2. (A) The apoptotic maps and cell apoptotic histogram of RL95-2 cells; (B) apoptotic maps and cell apoptotic histogram of KLE cell apoptosis; ${ }^{*} \mathrm{P}<0.05$ vs. the blank and NC groups; ${ }^{*} \mathrm{P}<0.05$ vs. the CP-31398 group. The statistical data are presented as the means \pm standard deviation and were analyzed using one-way ANOVA followed by a Tukey's post hoc test. The experiment was repeated 3 times. EC, endometrial cancer.

CP-31398 increases the EC cell apoptotic rate. To elucidate the effects of CP-31398 on EC cell apoptosis, we performed flow cytometry. Annexin V-FITC/PI results revealed that, in RL95-2 and KLE cells, compared with the blank and NC groups, the CP-31398, si-MDM2 and CP-31398 + si-MDM2 groups presented increased cell apoptosis rates $(\mathrm{P}<0.05)$, while the difference was not significant in the CP-31398 + oe-MDM2 group ( $>0.05)$ compared with the blank and NC groups. Compared with the CP-31398 group, the CP-31398 + si-MDM2 group exhibited a significantly increased cell apoptosis $(\mathrm{P}<0.05)$. The above-mentioned results demonstrated that $\mathrm{CP}-31398$ promoted the apoptosis of EC cells by downregulating the expression of MDM2 (Fig. 8).

CP-31398 impedes EC cell migratory ability. Subsequently, the scratch test was conducted to detect cell migration. The results indicated that cell migration in the CP-31398, si-MDM2 and CP-31398 + si-MDM2 groups decreased in RL95-2 and KLE cells compared to that in the blank and NC groups $(\mathrm{P}<0.05)$, while the difference was not significant in the $\mathrm{CP}-31398+$ oe-MDM2 group $(\mathrm{P}<0.05)$ compared with the blank and NC groups. Compared with the CP-31398 group, the CP-31398 + si-MDM2 group exhibited a significantly decreased cell migration $(\mathrm{P}<0.05)$. These results indicated that $\mathrm{CP}-31398$ inhibited the migration of EC cells by downregulating the expression of MDM2 (Fig. 9).

CP-31398 decreases EC cell invasive ability. Subsequently, the involvement of MDM2 in the effects of CP-31398 on cell invasion was examined. In the RL95-2 and KLE cells, the number of cells transferred from the upper chamber to the lower chamber decreased in the CP-31398, si-MDM2 and CP-31398 + si-MDM2 groups compared to the blank and NC groups $(\mathrm{P}<0.05)$, while the difference was not obvious in the CP-31398 + oe-MDM2 group $(\mathrm{P}<0.05)$ compared with the blank and NC groups. Compared with the CP-31398 group, the CP-31398 + si-MDM2 group exhibited a decreased number of cells transferred from the upper chamber to the lower chamber $(\mathrm{P}<0.05)$. These results revealed that $\mathrm{CP}-31398$ inhibited the invasion of EC cells by downregulating the expression of MDM2 (Fig. 10).

\section{Discussion}

EC plagues women worldwide, and a study conducted in 2014 suggested that approximately 74,000 women succumb to 
A

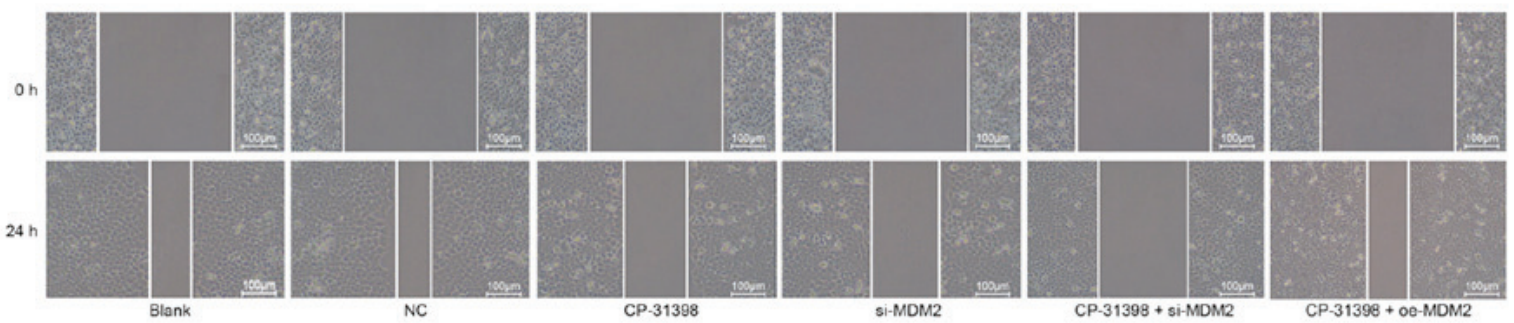

B

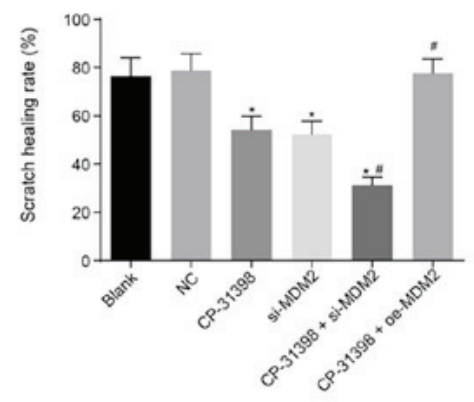

C

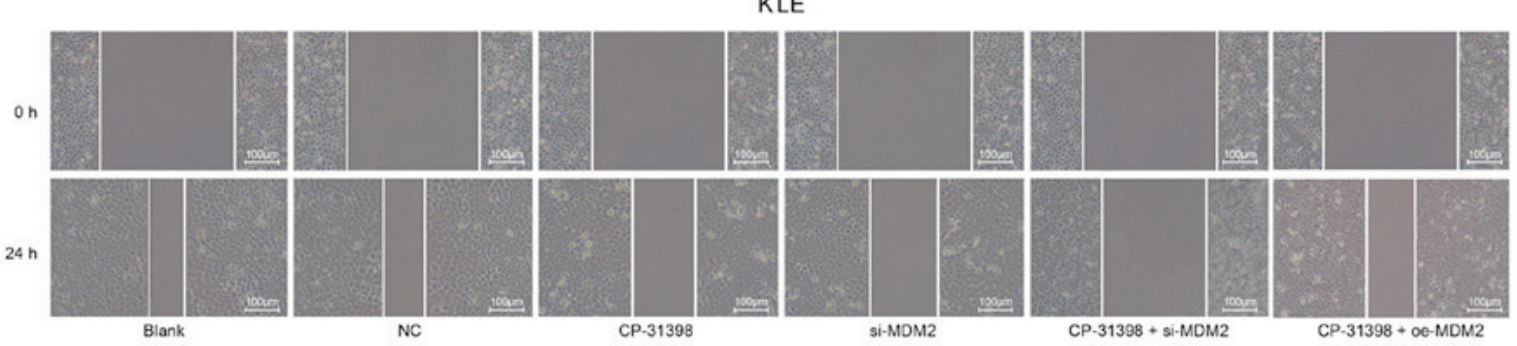

D

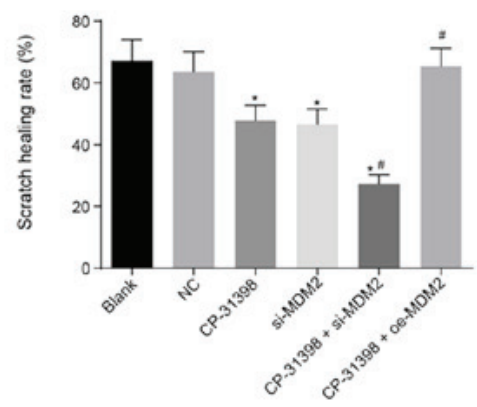

Figure 9. Decreased cell migration was found in EC cells treated with CP-31398 and si-MDM2. (A) The migration maps of RL95-2 cells (magnification, x100); (B) quantitative analysis of wound healing rate of RL95-2 cells; (C) the migration maps KLE cells (magnification, x100); (D) quantitative analysis of wound healing rate of KLE cells; ${ }^{*} \mathrm{P}<0.05$ vs. the blank and $\mathrm{NC}$ groups; ${ }^{\prime} \mathrm{P}<0.05$ vs. the $\mathrm{CP}-31398$ group. The statistical data are presented as the means \pm standard deviation and were analyzed using one-way ANOVA followed by a Tukey's post hoc test. The experiment was repeated 3 times. EC, endometrial cancer.

the disease each year (31). Therefore, understanding and identifying the molecular biology of EC are essential for the development of novel methods and therapies for the treatment of EC and to increase the quality of life of patients (32). In this study, we explored the involvement of CP-31398 and MDM2 in the migration, invasion and apoptosis of EC cells. Conclusively, we found that CP-31398 inhibited the migration and invasion and promoted the apoptosis of EC cells by downregulating the expression of MDM2.

In specific terms, we evaluated the expression of MMP-2 and MMP-9 due to their association with EC cell metastasis (33). Other factors, including p21, p53, Bad, Bax,
Bcl-2, Cox-2 and caspase-3 have also been demonstrated to be associated with EC cell metastasis (34-38). Thus, in this study, we detected these indexes that can reflect the development of EC to highlight that MDM2 can affect EC progression by regulating the levels of a number of proteins. Initially, one of our findings indicated that the expression of MDM2, MMP-2 and MMP-9 in EC tissues and cells was significantly higher. MDM2 is overexpressed in several types of human cancer, including hepatocellular carcinomas and breast cancer $(39,40)$. The overexpression of MDM2 in human cancers implies that the protein is beneficial for the progression of cancer cells (41). A previous meta-analysis found that the MDM2 SNP309 
A
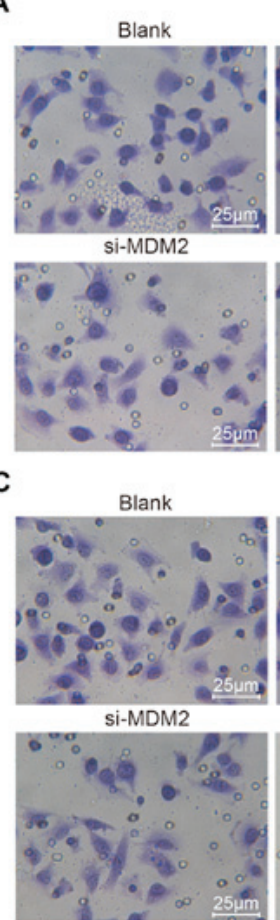
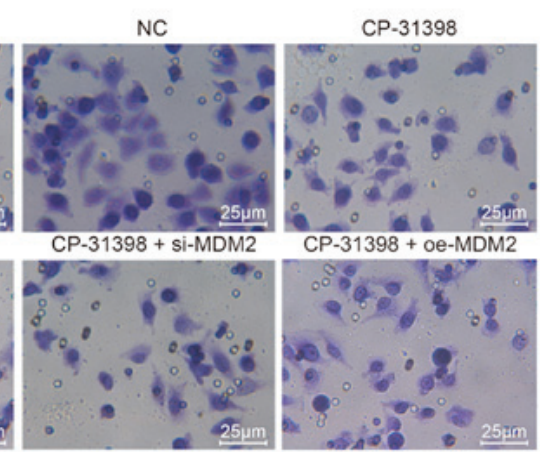

B

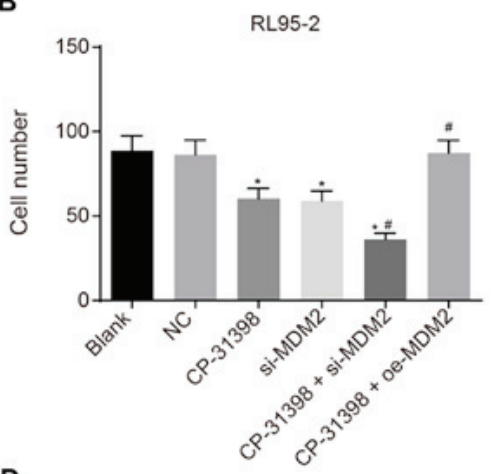

D
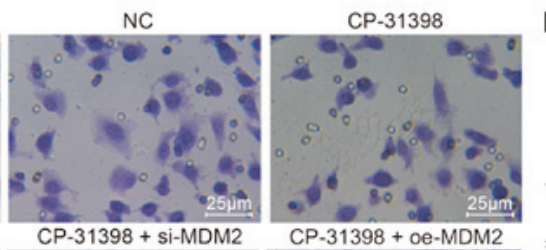
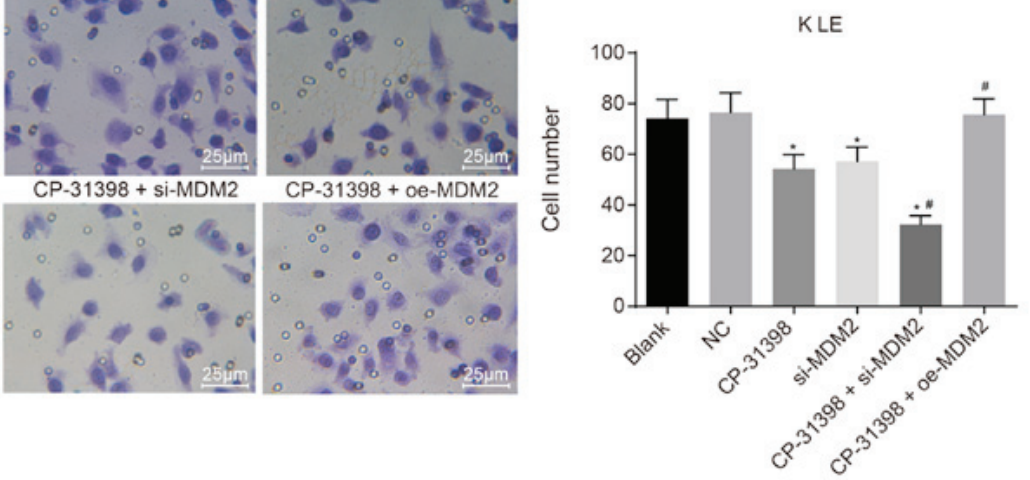

Figure 10. Cell invasion is decreased in EC cells treated with CP-31398 and si-MDM2. (A) The invasion maps of RL95-2 cells (magnification, $\mathrm{x} 400$ ); (B) quantitative analysis of invasion cell number of RL95-2 cells; (C) the invasion maps of KLE cells (magnification, x400); (D) quantitative analysis of invasion cell number of KLE cells; ${ }^{\mathrm{P}}<0.05$ vs. the blank and $\mathrm{NC}$ groups; ${ }^{\#} \mathrm{P}<0.05$ vs. the $\mathrm{CP}-31398$ group. The statistical data are presented as the means \pm standard deviation and analyzed using one-way ANOVA followed by a Tukey's post hoc test. The experiment was repeated 3 times. EC, endometrial cancer.

polymorphisms may be associated with an increased risk of EC (42). MMPs are a group of structural and functional related zinc-dependent endopeptidases, which play important roles in tumor invasion and tissue remodeling due to their ability to degrade extracellular matrix proteins (43). Among these, alterations in the expression levels of MMP-2 and MMP-9 are associated with the metastasis of breast and ovarian cancers $(44,45)$. Previously, it has been demonstrated that MMP-9 and MMP-2 are highly expressed in EC (46), which is consistent with our findings and further solidifies our results. In addition, we found that CP-31398 decreased the expression of MDM2, Bcl-2 and Cox-2, but increased the expression of p53, p21, Bad, Bax, Cyt-c and caspase-3. Cox-2 and Bcl-2 are known regulators of apoptosis that are overexpressed in numerous types of cancer (47). A previous study found that Cox-2 was overexpressed in EC and further promoted tumor growth (48). The elevated expression of Cox-2 has been previously shown to be associated with tumor migration, invasion and a poor prognosis in epithelial ovarian cancer (49). Bcl-2 family proteins (Bcl-2, Bad and Bax) are essential regulators for cellular death, and they primarily function by controlling the release of Cyt-c from the mitochondria in the endogenous apoptotic pathway (50). The overexpression of Bcl-2 has been found in EC and breast cancer (36). Moreover, the overexpression of Bcl-2 has been demonstrated to be capable of inducing cellular metastasis in breast cancer through epithelial-to-mesenchymal transition (51). p53 is the most commonly mutated tumor suppressor gene in human cancers and serves as an independent prognostic factor in EC $(52,53)$. Mammalian Cyt-c plays an active role in cellular growth and death and functions as a trigger of apoptosis (54). Studies have indicated that p53, p21, $\mathrm{Bax}, \mathrm{Bad}, \mathrm{Cyt}-\mathrm{c}$ and caspase-3 are pro-apoptotic, and $\mathrm{Bcl}-2$ is anti-apoptotic $(55,56)$. MDM2 is reported to be a key negative regulator of tumor protein p53 (57). CP-31398 is a known regulator of $\mathrm{Bax}, \mathrm{Bcl}-2$, caspase- 3 and MDM2 expression, and prevents the growth of xenograft tumors in p53-mutated colorectal cancer (14). These findings and evidence demonstrate that CP-31398 promotes the expression of pro-apoptotic factors in EC cells via the downregulation of MDM2.

Furthermore, the findings of this study revealed that CP-31398 inhibited cell migratory and invasive abilities, but promoted cell apoptosis in EC. MDM2 SNP309 polymorphism has previously been reported to increase the risk of EC (42). The combination of p53 codon 72 and MDM2 SNP309 polymorphisms has been shown to be associated with an increased risk of EC (58). The overexpression of p53 is notably associated with a high pathological grade and LNM in EC specimens (59). The dominant negative mutation $\mathrm{R} 273 \mathrm{H}$ of tumor suppressor p53 has been shown to promote the invasive and migratory abilities of EC (60). CP-31398 is a prototype small molecule stabilizing the conformation of p53 and facilitates p53 activity in cancer cells with mutant or wild-type p53 (61). MDM2 is a p53-specific E3 ubiquitin ligase and the principal cellular antagonist of p53, which acts to attenuate the p53 growth-suppressive function in unstressed cells (62). p53 stabilization induced by CP-31398 is implicated in tumor suppression in cancers with a high MDM2 expression (63). These findings indicate that CP-31398 prevents the migration 
and invasion, and induces the apoptosis of EC cells via the downregulation of MDM2.

In conclusion, the findings of the present study indicated that CP-31398 inhibited the migration and invasion, and induced the apoptosis of EC cells through the downregulation of MDM2. This study elucidates the mechanism of action of MDM2 and its role in EC and therapeutic implications in the treatment of EC. Further research and studies are required in order to reduce the plight of patients with EC and to increase the quality of life.

\section{Acknowledgements}

The authors would like to give their sincere appreciation to the reviewers for their helpful comments regarding this article.

\section{Funding}

The study was supported by National Natural Science Foundation of China (No. 81702967); National Health and Family Planning Commission of Henan Province (No. 201601010); and the Science and Technology Department of Henan Province (No. 161100311100; 162300410269; 172102310168; 162102310131).

\section{Availability of data and materials}

The datasets used and/or analyzed during the current study are available from the corresponding author on reasonable request.

\section{Authors' contributions}

LL, LY, CCR and XAZ conceived and designed the study. HC, YNC and FZ were involved in data collection. LL, SF and JP performed the statistical analysis and preparation of figures. LY and XAZ drafted the paper. CCR and HC contributed substantially to the revision of the manuscript. All authors have read and approved the final manuscript.

\section{Ethics approval and consent to participate}

The study was approved by the Clinical Ethics Committee of the Third Affiliated Hospital of Zhengzhou University (Zhengzhou, China). Informed consents were obtained from all subjects participating in this study.

\section{Patient consent for publication}

Not applicable.

\section{Competing interests}

The authors declare that they have no competing interests.

\section{References}

1. Liang H, Cheung LW, Li J, Ju Z, Yu S, Stemke-Hale K, Dogruluk T, Lu Y, Liu X, Gu C, et al: Whole-exome sequencing combined with functional genomics reveals novel candidate driver cancer genes in endometrial cancer. Genome Res 22: 2120-2129, 2012.
2. Sorosky JI: Endometrial cancer. Obstet Gynecol 120: 383-397, 2012.

3. Myatt SS, Wang J, Monteiro LJ, Christian M, Ho KK, Fusi L, Dina RE, Brosens JJ, Ghaem-Maghami S and Lam EW: Definition of microRNAs that repress expression of the tumor suppressor gene FOXO1 in endometrial cancer. Cancer Res 70: 367-377, 2010.

4. May K, Bryant A, Dickinson HO, Kehoe S and Morrison J: Lymphadenectomy for the management of endometrial cancer. Cochrane Database Syst Rev 1: CD007585, 2010.

5. Gunter MJ,Hoover DR, Yu H, Wassertheil-Smoller S, Manson JE, Li J, Harris TG, Rohan TE, Xue X, Ho GY, et al: A prospective evaluation of insulin and insulin-like growth factor-I as risk factors for endometrial cancer. Cancer Epidemiol Biomarkers Prev 17: 921-929, 2008.

6. Bosse T, Peters EE, Creutzberg CL, Jürgenliemk-Schulz IM, Jobsen JJ, Mens JW, Lutgens LC, van der Steen-Banasik EM, Smit VT and Nout RA: Substantial lymph-vascular space invasion (LVSI) is a significant risk factor for recurrence in endometrial cancer - A pooled analysis of PORTEC 1 and 2 trials. Eur J Cancer 51: 1742-1750, 2015.

7. Sanz-Chávez TL, Vilar-Compte D, de Nicola-Delfín L and Meneses-García A: Overweight, obesity, diabetes, and hypertension in endometrial cancer. Rev Med Inst Mex Seguro Soc 51: 326-329, 2013 (In Spanish).

8. Shafiee MN, Chapman C, Barrett D, Abu J and Atiomo W: Reviewing the molecular mechanisms which increase endometrial cancer (EC) risk in women with polycystic ovarian syndrome (PCOS): Time for paradigm shift? Gynecol Oncol 131: 489-492, 2013.

9. Wright JD, Barrena Medel NI, Sehouli J, Fujiwara K and Herzog TJ: Contemporary management of endometrial cancer. Lancet 379: 1352-1360, 2012.

10. Johnson WD, Muzzio M, Detrisac CJ, Kapetanovic IM, Kopelovich L and McCormick DL: Subchronic oral toxicity and metabolite profiling of the p53 stabilizing agent, CP-31398, in rats and dogs. Toxicology 289: 141-150, 2011.

11. Kapetanovic IM, Muzzio M, McCormick DL, Thompson TN, Johnson WD, Horn TL, Mohammed A, Rao CV and Kopelovich L: Pharmacokinetics and tissue and tumor exposure of CP-31398, a p53-stabilizing agent, in rats. Cancer Chemother Pharmacol 69: 1301-1306, 2012.

12. Madka V, Zhang Y, Li Q, Mohammed A, Sindhwani P, Lightfoot S, Wu XR, Kopelovich L and Rao CV: p53-stabilizing agent $\mathrm{CP}-31398$ prevents growth and invasion of urothelial cancer of the bladder in transgenic UPII-SV40T mice. Neoplasia 15: 966-974, 2013.

13. He XX, Zhang YN, Yan JW, Yan JJ, Wu Q and Song YH: CP-31398 inhibits the growth of p53-mutated liver cancer cells in vitro and in vivo. Tumour Biol 37: 807-815, 2016

14. He X, Kong X, Yan J, Yan J, Zhang Y, Wu Q, Chang Y, Shang H, Dou Q, Song Y, et al: CP-31398 prevents the growth of p53-mutated colorectal cancer cells in vitro and in vivo. Tumour Biol 36: 1437-1444, 2015.

15. Fiorini C, Menegazzi M, Padroni C, Dando I, Dalla Pozza E, Gregorelli A,Costanzo C,Palmieri M and Donadelli M: Autophagy induced by $\mathrm{p} 53$-reactivating molecules protects pancreatic cancer cells from apoptosis. Apoptosis 18: 337-346, 2013.

16. Xu J, Timares L, Heilpern C, Weng Z, Li C, Xu H, Pressey JG, Elmets CA, Kopelovich L and Athar M: Targeting wild-type and mutant p53 with small molecule CP-31398 blocks the growth of rhabdomyosarcoma by inducing reactive oxygen species-dependent apoptosis. Cancer Res 70: 6566-6576, 2010.

17. Hashemi M, Omrani M, Eskandari-Nasab E, Hasani SS, Mashhadi MA and Taheri M: A 40-bp insertion/deletion polymorphism of Murine Double Minute2 (MDM2) increased the risk of breast cancer in Zahedan, Southeast Iran. Iran Biomed J 18: 245-249, 2014

18. Lu X, Yan C, Huang Y, Shi D, Fu Z, Qiu J and Yin Y: Mouse double minute 2 (MDM2) upregulates Snail expression and induces epithelial-to-mesenchymal transition in breast cancer cells in vitro and in vivo. Oncotarget 7: 37177-37191, 2016.

19. Roszak A, Misztal M, Sowińska A and Jagodziński PP: Murine double-minute 2 homolog single nucleotide polymorphisms 285 and 309 in cervical carcinogenesis. Mol Diagn Ther 19: 235-244, 2015.

20. Gu J, Tang Y, Liu Y, Guo H, Wang Y, Cai L, Li Y and Wang B: Murine double minute 2 siRNA and wild-type p53 gene therapy enhances sensitivity of the SKOV3/DDP ovarian cancer cell line to cisplatin chemotherapy in vitro and in vivo. Cancer Lett 343: 200-209, 2014 
21. Nakajima N, Ito Y, Yokoyama K, Uno A, Kinukawa N, Nemoto N and Moriyama M: The Expression of murine double minute 2 (MDM2) on Helicobacter pylori-infected intestinal metaplasia and gastric cancer. J Clin Biochem Nutr 44: 196-202, 2009.

22. Demma MJ, Wong S, Maxwell E and Dasmahapatra B: CP-31398 restores DNA-binding activity to mutant p53 in vitro but does not affect p53 homologs p63 and p73. J Biol Chem 279: 45887-45896, 2004.

23. Haltia UM,Bützow R, Leminen A and Loukovaara M: FIGO 1988 versus 2009 staging for endometrial carcinoma: A comparative study on prediction of survival and stage distribution according to histologic subtype. J Gynecol Oncol 25: 30-35, 2014.

24. Zhong H, De Marzo AM, Laughner E, Lim M, Hilton DA, Zagzag D, Buechler P, Isaacs WB, Semenza GL and Simons JW: Overexpression of hypoxia-inducible factor 1alpha in common human cancers and their metastases. Cancer Res 59: 5830-5835, 1999.

25. Karber G: Determination of median lethal dose. Arch Exp Pathol Pharmacol. 162: 480, 1931

26. Halevy T, Czech $\mathrm{C}$ and Benvenisty N: Molecular mechanisms regulating the defects in fragile $\mathrm{X}$ syndrome neurons derived from human pluripotent stem cells. Stem Cell Reports 4: 37-46, 2015.

27. Livak KJ and Schmittgen TD: Analysis of relative gene expression data using real-time quantitative PCR and the 2(-Delta Delta C(T)) method. Methods 25: 402-408, 2001

28. Ayuk SM, Abrahamse H and Houreld NN: The role of photobiomodulation on gene expression of cell adhesion molecules in diabetic wounded fibroblasts in vitro. J Photochem Photobiol B 161: 368-374, 2016.

29. Yao Y, Suo AL, Li ZF, Liu LY, Tian T, Ni L, Zhang WG, Nan KJ, Song TS and Huang C: MicroRNA profiling of human gastric cancer. Mol Med Rep 2: 963-970, 2009.

30. Fang Y, Chen H,Hu Y, Li Q, Hu Z, Ma T and Mao X: Burkholderia pseudomallei-derived miR-3473 enhances NF- $\kappa \mathrm{B}$ via targeting TRAF3 and is associated with different inflammatory responses compared to Burkholderia thailandensis in murine macrophages. BMC Microbiol 16: 283, 2016.

31. Bell DW: Novel genetic targets in endometrial cancer. Expert Opin Ther Targets 18: 725-730, 2014.

32. Bansal N, Yendluri V and Wenham RM: The molecular biology of endometrial cancers and the implications for pathogenesis, classification, and targeted therapies. Cancer Contr 16: 8-13, 2009

33. Planagumà J, Liljeström M, Alameda F, Bützow R, Virtanen I, Reventós J and Hukkanen M: Matrix metalloproteinase-2 and matrix metalloproteinase- 9 codistribute with transcription factors RUNX1/AML1 and ETV5/ERM at the invasive front of endometrial and ovarian carcinoma. Hum Pathol 42: 57-67, 2011.

34. Yoneda T, Kuboyama A, Kato K, Ohgami T, Okamoto K, Saito T and Wake N: Association of MDM2 SNP309 and TP53 Arg72Pro polymorphisms with risk of endometrial cancer. Oncol Rep 30: 25-34, 2013.

35. Tang W, He X, Chan Y and Luo Y: Lack of association between p53 codon 72 polymorphism and endometrial cancer: A meta-analysis. Cancer Epidemiol 36: e153-e157, 2012

36. Dorjgochoo T, Xiang YB, Long J, Shi J, Deming S, Xu WH, Cai H, Cheng J, Cai Q, Zheng W, et al: Association of genetic markers in the BCL-2 family of apoptosis-related genes with endometrial cancer risk in a Chinese population. PLoS One 8: e60915, 2013.

37. Ma X, Hui Y, Lin L, Wu Y, Zhang X and Liu P: Clinical significance of COX-2, GLUT-1 and VEGF expressions in endometrial cancer tissues. Pak J Med Sci 31: 280-284, 2015.

38. Wang XF, Zhao YB, Wu Q, Sun ZH and Li HJ: Triptolide induces apoptosis in endometrial cancer via a p53 independent mitochondrial pathway. Mol Med Rep 9: 39-44, 2014.

39. Jiang D, Cho W, Li Z, Xu X, Qu Y, Jiang Z, Guo L and Xu G: miR-758-3p suppresses proliferation, migration and invasion of hepatocellular carcinoma cells via targeting MDM2 and mTOR Biomed Pharmacother 96: 535-544, 2017

40. Haupt S, Vijayakumaran R, Miranda PJ, Burgess A, Lim E and Haupt Y: The role of MDM2 and MDM4 in breast cancer development and prevention. J Mol Cell Biol 9: 53-61, 2017.

41. Deb SP, Singh S and Deb S: MDM2 overexpression, activation of signaling networks, and cell proliferation. Subcell Biochem 85 215-234, 2014

42. Peng Q, Mo C, Qin A, Lao X, Chen Z, Sui J, Wu J, Zhai L, Yang S, Qin X, et al: MDM2 SNP309 polymorphism contributes to endometrial cancer susceptibility: Evidence from a meta-analysis. J Exp Clin Cancer Res 32: 85, 2013.
43. Köhrmann A, Kammerer U, Kapp M, Dietl J and Anacker J: Expression of matrix metalloproteinases (MMPs) in primary human breast cancer and breast cancer cell lines: New findings and review of the literature. BMC Cancer 9: 188, 2009.

44. Li H, Qiu Z, Li F and Wang C: The relationship between MMP-2 and MMP-9 expression levels with breast cancer incidence and prognosis. Oncol Lett 14: 5865-5870, 2017.

45. Hu X, Li D, Zhang W, Zhou J, Tang B and Li L: Matrix metalloproteinase-9 expression correlates with prognosis and involved in ovarian cancer cell invasion. Arch Gynecol Obstet 286: $1537-1543,2012$.

46. Grybos A and Bar J: The relationships between the immunoexpression of KAI1, MMP-2, MMP-9 and steroid receptors expression in endometrial cancer. Folia Histochem Cytobiol 52: 187-194, 2014.

47. Yang Y, Zhu J, Gou H, Cao D, Jiang M and Hou M: Clinical significance of Cox-2, Survivin and Bcl-2 expression in hepatocellular carcinoma (HCC). Med Oncol 28: 796-803, 2011.

48. Hasegawa K, Torii Y, Ishii R, Oe S, Kato R and Udagawa Y: Effects of a selective COX-2 inhibitor in patients with uterine endometrial cancers. Arch Gynecol Obstet 284: 1515-1521, 2011.

49. Uddin S, Ahmed M, Hussain A, Assad L, Al-Dayel F, Bavi P, Al-Kuraya KS and Munkarah A: Cyclooxygenase-2 inhibition inhibits PI3K/AKT kinase activity in epithelial ovarian cancer. Int J Cancer 126: 382-394, 2010.

50. Vogler M: BCL2A1: The underdog in the BCL2 family. Cell Death Differ 19: 67-74, 2012

51. Du C, Zhang X, Yao M, Lv K, Wang J, Chen L, Chen Y, Wang $\mathrm{S}$ and $\mathrm{Fu} \mathrm{P}$ : $\mathrm{Bcl}-2$ promotes metastasis through the epithelial-to-mesenchymal transition in the BCap37 medullary breast cancer cell line. Oncol Lett 15: 8991-8898, 2018.

52. Dong P, Xu Z, Jia N, Li D and Feng Y: Elevated expression of p53 gain-of-function mutation $\mathrm{R} 175 \mathrm{H}$ in endometrial cancer cells can increase the invasive phenotypes by activation of the EGFR/PI3K/AKT pathway. Mol Cancer 8: 103, 2009.

53. Jongen VH, Briët JM, de Jong RA, Joppe E, ten Hoor KA, Boezen HM, Evans DB, Hollema H, van der Zee AG and Nijman HW: Aromatase, cyclooxygenase 2, HER-2/neu, and p53 as prognostic factors in endometrioid endometrial cancer. Int J Gynecol Cancer 19: 670-676, 2009.

54. Mahapatra G, Varughese A, Ji Q, Lee I, Liu J, Vaishnav A, Sinkler C, Kapralov AA, Moraes CT, Sanderson TH, et al: Phosphorylation of Cytochrome c Threonine 28 Regulates Electron Transport Chain Activity in Kidney: IMPLICATIONS FOR AMP KINASE. J Biol Chem 292: 64-79, 2017.

55. Gosslau A, Pabbaraja S, Knapp S and Chen KY: Trans- and cis-stilbene polyphenols induced rapid perinuclear mitochondrial clustering and p53-independent apoptosis in cancer cells but not normal cells. Eur J Pharmacol 587: 25-34, 2008.

56. Sayeed I, Parvez S, Wali B, Siemen D and Stein DG: Direct inhibition of the mitochondrial permeability transition pore: A possible mechanism for better neuroprotective effects of allopregnanolone over progesterone. Brain Res 1263: 165-173, 2009.

57. Hu L, Zhang H, Bergholz J, Sun S and Xiao ZX: MDM2/MDMX Master negative regulators for p53 and RB. Mol Cell Oncol 3: e1106635, 2016.

58. Nunobiki O, Ueda M, Yamamoto M, Toji E, Sato N, Izuma S, Okamoto Y, Torii K and Noda S: Polymorphisms of p53 codon 72 and MDM2 promoter 309 and the risk of endometrial cancer. Hum Cell 22: 101-106, 2009.

59. Wang H, Bao W, Jiang F, Che Q, Chen Z, Wang F, Tong H, Dai C, He X, Liao Y, et al: Mutant p53 (p53-R248Q) functions as an oncogene in promoting endometrial cancer by up-regulating REG $\gamma$. Cancer Lett 360: 269-279, 2015.

60. Dong P, Tada M, Hamada J, Nakamura A, Moriuchi T and Sakuragi N: p53 dominant-negative mutant $\mathrm{R} 273 \mathrm{H}$ promotes invasion and migration of human endometrial cancer HHUA cells. Clin Exp Metastasis 24: 471-483, 2007.

61. Wischhusen J, Naumann U, Ohgaki H, Rastinejad F and Weller M: CP-31398, a novel p53-stabilizing agent, induces p53-dependent and p53-independent glioma cell death. Oncogene 22: 8233-8245, 2003.

62. Moll UM and Petrenko O: The MDM2-p53 interaction. Mol Cancer Res 1: 1001-1008, 2003.

63. Wang W, Takimoto R, Rastinejad F and El-Deiry WS: Stabilization of $\mathrm{p} 53$ by CP-31398 inhibits ubiquitination without altering phosphorylation at serine 15 or 20 or MDM2 binding. Mol Cell Biol 23: 2171-2181, 2003.

This work is licensed under a Creative Commons Attribution-NonCommercial-NoDerivatives 4.0 International (CC BY-NC-ND 4.0) License. 